\title{
A paranóia nos negros: estudo clínico e médico-legal (1903)* Parte 3 (final)
}

Raimundo Nina-Rodrigues

\section{III - Formas clínicas da paranóia nos pretos brasileiros (continuação)}

D) Paranóia aguda (Westphal, Gramer, Schule, Mendel, Tomino, Del Grecco, Séglas, G. Ballet, Julio de Mattos etc.). Delírios súbitos e polimorfos. Surtos (bouffées) delirantes (Magnan, Legrain etc.) etc.

A existência de delírios sistematizados de curta duração, mais ou menos efêmeros e de grande intensidade, a freqüente associação entre diversas formas clínicas da paranóia com estados de confusão mental permitem representar exatamente a paranóia aguda, cuja existência só choca aqueles que confundem a degenerescência paranóica com o delírio sistematizado paranóico ou Verrücktheit.

* Artigo originalmente publicado sob o título "La paranoïa chez les nègres”, Archives d'Anthropologie Criminelle, de Criminologie et de Psychologie Normale et Pathologique, Lyon, ano 18, n. 118, p. 609-51 e n. 119, p. 689-714, 1903. Tradução de Martha Gambini. Revisão técnica de Ana Maria G. R. Oda.

As Partes 1 e 2 foram publicadas nos dois números anteriores da Revista Latinoamericana de Psicopatologia Fundamental, ano VII, n. 2, p. 161-78, jun./ 2004 e ano VII, n. 3, p. 131-58, set./ 2004. 
Feita essa distinção, compreendemos facilmente que, se não podemos admitir uma forma aguda da degenerescência paranóica, é perfeitamente permitido aceitar a revelação dessa degenerescência por um delírio sistematizado agudo.

É aqui que se passa naturalmente a forma sistematizada dos delírios de início súbito. As relações que esses delírios freqüentemente têm com a confusão mental podem opor algumas dificuldades para a compreensão da paranóia aguda. Entretanto, Séglas (1897, p. 384) demonstrou que é possível distinguir, mesmo clinicamente, a confusão mental primitiva da paranóia aguda confusional, e Del Grecco (1877-78), que é de opinião que no delírio sistematizado paranóico há sempre um elemento confusional alucinatório, interpreta bem, acreditamos, os casos intermediários. Ele admite que possa haver: $1^{\circ}$ ) uma simples coexistência da confusão mental com a paranóia; temos então a confusão mental paranóica; $2^{\circ}$ ) a confusão mental, desenvolvendo-se em um terreno paranóico, adquire traços particulares e constitui a confusão mental paranóide.

A existência da paranóia aguda é freqüente nos negros e nos mestiços. Ela pode ser encontrada tanto sob a forma de delírio de início súbito quanto sob aquela de confusão mental paranóide.

Para não alongar este artigo, talvez já excessivamente longo, iremos nos limitar às duas observações seguintes que demonstram a verdade de nossa asserção. Não é possível, compreende-se, tentar realizar aqui o estudo das relações entre a paranóia aguda, as demências precoces, a demência paranóide de Kraepelin, os delírios alucinatórios etc. Basta então fazer notar que, no que se refere à paranóia aguda, nos colocamos ao lado das idéias de Séglas.

\section{Observação XII (pessoal; resumida)}

Paranóia aguda em um negro degenerado. Alucinações; delírio de perseguição e de grandeza. Internação. Melhora; exeat (alta).

Jacinto Nascimento, pedreiro, com mais ou menos cinqüenta e cinco anos, negro, com uma assimetria facial notável, entrou no Asilo São João de Deus, na Bahia, em 23 de abril de 1902.

A doença começou com idéias de enfeitiçamento, do qual ele tomou conhecimento pela presença de um gato preto em sua casa. Ao mesmo tempo, tinha idéias de grandeza e idéias religiosas. Ele tinha ganhado grandes prêmios na loteria, da qual comprava muitos bilhetes. Tudo lhe pertencia: as casas vizinhas, a estação ferroviária que ficava perto de onde ele morava. Certo dia ficou muito excitado, quebrou em pedacinhos todo seu mísero mobiliário que estava amontoado, e depois saiu pelas ruas gritando: “Viva São João!”. Ele escutava vozes que lhe indicavam lugares onde havia tesouros escondidos e escavava o chão com as mãos. Tornou-se agressivo, e então foi preso e internado no asilo. 
Seu estado melhorou rapidamente, e após mais ou menos seis meses obteve seu exeat, em 13 de outubro de 1902, considerado curado.

\section{Observação XIII (pessoal)}

Paranóia aguda alucinatória numa mulata portadora de estigmas de degenerescência. Terminação brusca.

Francina M.P., é uma mulata de quarenta e três anos, solteira, muito trabalhadeira, de bons costumes (conservou sua virgindade) e muito afeita a práticas religiosas. Assimetria facial bastante acentuada. O pai teve um breve acesso de loucura, de natureza desconhecida. Após um ataque de apoplexia, uma de suas irmãs apresentou um caso de cegueira verbal, curioso por sua nitidez, e que causou a perda de seu emprego. Como ela morava com Francina, a condição de existência material das duas mulheres tornou-se a partir daí muito difícil. Os cuidados que devia ter com a irmã doente não mais permitiam a Francina que se dedicasse tão ativamente ao trabalho, o que fez seus ganhos diminuírem, exatamente quando as despesas ocasionadas pela doença agravavam a situação. Francina impôs-se um acréscimo de trabalho que não lhe deixava mais o tempo de repouso necessário. Passava as noites à cabeceira da irmã, cujo caráter, modificado pela doença, tornou-se irritável e extremamente exigente. Era uma verdadeira luta. O ano de 1896 decorreu nessas condições. Em janeiro de 1897, Francina sentia-se cansada, tornou-se triste, preocupada e freqüentava assiduamente as igrejas. Sua piedade era exagerada. Após alguns meses passados nessas condições, ela começou a se queixar de que a estavam perseguindo; poucos dias depois, um delírio de perseguição com alucinações auditivas e idéias de danação se manifestam abertamente. São negros feiticeiros que a insultam e a perseguem por toda parte; que dizem que ela tem o diabo no corpo. As idéias de danação se acentuam. Ela quer fugir da igreja; não consegue mais rezar, pois Deus não a atenderia, já que o diabo está em seu corpo. Quando, ainda assim, às vezes ela queria rezar, os maus pensamentos se apoderavam de seu espírito, e, sem querer, ela blasfemava (impulsão verbal). Ela estava muito abatida. Mais tarde, necessidades de natureza impulsiva de sair e de correr pelas ruas se manifestam: ela quer pular das janelas; sua excitação é extrema, ela anda sem parar, escuta os negros que a insultam e a perseguem; idéias de suicídio se mostram. É essa a situação em novembro.

Como a família desejasse interná-la, nós lhe fornecemos um certificado atestando o estado mental de Francina e demos as indicações necessárias sobre as formalidades a serem cumpridas para atingir o objetivo desejado. Mas enquanto as providências eram tomadas, o estado mental da doente melhorou subitamente e encaminhou-se, a partir daí, para uma cura rápida, o que tornava a internação inútil. 


\section{E) Paranóia indiferente ou sem delírio (Tanzi e Riva, Morselli)}

Tanzi e Riva encerram todos os matóides, * todos os desequilibrados, todos os casos de loucura lúcida, na paranóia indiferente; nada nos parece mais artificial.

Há, entretanto, algo de feliz na concepção desses autores: é que ela é uma tentativa, um início de distinção psicológica das diferentes espécies de monstruosidades do espírito que até aqui eram todas englobadas, de forma pouco metódica, sob o nome de degenerados. Hoje, seria a vez dos paranóicos, amanhã dos epilépticos, depois dos criminais etc.

De fato, é evidente que compreendemos no grupo dos desequilibrados ou matóides todos os casos em que o desarranjo psíquico que deveria levar a uma das formas completas da degenerescência mental, não chegou a seu termo, e produziu apenas casos frustrados, isto é, indivíduos inconseqüentes, desequilibrados.

Seria então conveniente distinguir e caracterizar entre os matóides, os paranóicos sem delírio, os epilépticos frustrados, os criminais incompletos etc. Alguns autores negaram a possibilidade dessa distinção. Visando não considerar como parte integrante da doença o desequilibrado paranóico da infância, porque nessa idade o delírio ainda não é possível, Marcio Nery contesta a existência da paranóia originária:

As manifestações anormais dos predispostos - ele afirma - não são casos particulares à paranóia, mas são comuns a todas as formas degenerativas. O que se nota num candidato à paranóia, nota-se nos que se tornarão histéricos, epilépticos, loucos morais, degenerados inferiores etc. Nada de característico se apresenta que pudesse prever a eclosão da doença num período mais avançado da existência. (Nery, 1894, p. 26)

Evidentemente, há uma distinção a ser feita. Da verificação de um estado de desequilíbrio mental mal definido, não se pode sempre, não há dúvida, concluir com certeza sobre a manifestação de uma das formas determinadas, completas, da degenerescência psíquica. Mas isso não se opõe de forma alguma a que se descubra, nas anomalias de caráter do simples desequilibrado, os sinais psicológicos característicos de tal ou tal degenerescência especial que somente se concluirá mais tarde ou talvez nunca, já se manifestando agora indefinidamente sob a forma de casos não plenamente desenvolvidos. A impulsividade epiléptica, a lógica particular dos paranóicos, uma manifestação qualquer da insensibilidade moral dos loucos morais etc., podem muito bem se apresentar nos desequilibrados

* Matóide significa doido, desequilibrado, alienado; vem do italiano mattoide: pessoa impulsiva, irracional, privada de razão (nota da revisora técnica). 
que nunca apresentaram as manifestações motoras ou psíquicas do epilético, que nunca sofreram do delírio paranóico de perseguição ou de grandeza ou que não chegaram à anestesia moral completa do idiota moral. E quando Maudsley (1883, p. 317) esforçou-se para delimitar no matóide ou no temperamento vesânico formas clínicas particulares, ele nada mais fez senão buscar estabelecer essa distinção.

Ora, é claro que entre as variedades clínicas que ele descreveu, as variedades egoísta e suspeitosa se relacionam evidentemente à paranóia sem delírio, enquanto a variedade hesitante ou loucura da dúvida se liga antes aos delírios de negação ou de contraste, e as variedades avara e imoral podem ser consideradas filhas da loucura moral e do crime.

Krafft-Ebing fez a seguinte observação, e não sem razão:

Na infância, a alienação mental raramente chega até as idéias delirantes sistemáticas, como na paranóia dos adultos, ainda que os sintomas dessa variedade patológica (imaginação fantástica, delírios primordiais e passageiros como substrato das idéias fixas ulteriores) possam remontar até os primeiros anos da infância. (1897, p. 411)

As leis da psicologia nos dão, de fato, uma clara explicação da possibilidade que a paranóia possui de se manifestar mesmo na ausência do delírio; Paulhan demonstrou isso em trabalhos de fina análise psicológica. Acima das leis de associação, com auxílio das quais a escola associacionista inglesa acredita explicar qualquer organização mental, talvez uma lei mais geral, única, domine o princípio de sistematização. A coordenação, a sistematização dos elementos psíquicos têm sua causa e fundamento na organização fisiológica. Isto é mostrado de forma superabundante pelo exemplo citado por Bain, em que uma tempestade que causou a enchente dos rios, arrancando as árvores, derrubando as casas e semeando terror por toda parte, sugere séries de pensamentos diferentes: a mulher do marinheiro, que pensa em seu marido que está no mar, o comerciante, o corretor de seguros, o fazendeiro, o moleiro, o meteorologista, o poeta e o homem religioso.

Vemos - escreve Paulhan (1899) - que o fenômeno percebido desperta em cada um de nós séries e complexos particulares de fenômenos, segundo a organização própria do espírito que o recebe... Há aí um sistema de hábitos que acolhe tal estado de consciência, permitindo-lhe desenvolver-se, e que rejeita tal outro ou o paralisa em seu desenvolvimento, segundo uma lei bem evidente de finalidade interna. O fato notável no caso citado por Bain é que em toda parte é a tendência à unidade que domina, a unidade de fim, a sistematização dos estados de consciência e das tendências inconscientes ou semiconscientes; é essa sistematização que constitui o que chamamos uma personalidade ou um 


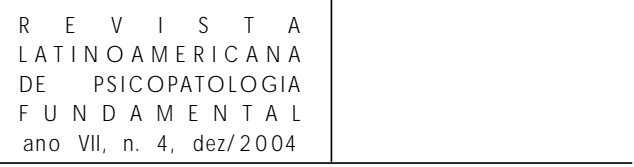

caráter. Cada qual tem seus sistemas próprios de hábitos, e é essa lei geral de harmonia ou finalidade existente em cada um de nós, sob diferentes formas, que determina e regula o jogo do espírito. (p. 411)

Ora, o desvio mental paranóico caracteriza-se inteiramente pelo orgulho e pela desconfiança, produto da parada de desenvolvimento psíquico no momento defensivo do instinto de conservação, representado pela falta de simpatia associada ao autofilismo mais elevado.

Nessa condição, o orgulho e a desconfiança serão a nota dominante dessas organizações mentais; todos os atos, todos os pensamentos desses indivíduos seguirão o caminho traçado; seus sentimentos de orgulho e de desconfiança irão polarizar nesse sentido sua atividade mental e darão ao paranóico sua fisionomia especial de sistematização.

Mas essa situação não supõe nem impõe necessariamente a existência do delírio. Existe sempre, nos indivíduos normais, uma sistematização especial que decorre da própria organização mental; é ela que dá a finalidade particular a todos os seus atos, a todos seus pensamentos, e é dela que cada um de nós tira sua personalidade; da mesma forma e fora do delírio, uma sistematização correspondente deve caber aos seres anormais. Entretanto, há uma diferença: é que, nos paranóicos, a sistematização toma proporções exageradas e não tolera as oscilações e as adaptações do homem normal; ela cristaliza o indivíduo na direção dada, o que é uma conseqüência de sua monstruosidade psíquica. Quando o paranóico cai no delírio, essa situação somente adquiriu seu máximo de intensidade porque, como as leis da psicologia mórbida são as mesmas que as da psicologia normal, há naturalmente uma sistematização delirante, como há uma normal, principalmente se o elemento confusional do delírio se reduz a um mínimo, o que deixa ao alienado uma grande lucidez, como acontece nos casos clássicos da loucura sistematizada primitiva.

Em resumo, consideramos o paranóico sem delírio não um matóide qualquer, mas apenas aquele que apresenta, sem acompanhamento de delírio, essa organização mental particular, ou seja, a sistematização de toda sua atividade mental no sentido do orgulho e da desconfiança.

Conhecemos casos de paranóia em negros e mestiços que confirmam essa opinião.

\section{Observação XIV (pessoal)}

Mestiço escuro, matóide. Sentimento de orgulho pronunciado. Tendência às idéias de grandeza e falta de senso crítico acentuado a ponto de permitir a formação de uma convicção equivalente a um verdadeiro delírio. Exercício correto de sua modesta profissão. 
Cândido V. dos Santos, com quase cinqüenta anos, é filho de um negro e de uma mulata. Assimetria crânio-facial exagerada a ponto de fazer seu rosto descrever um arco de círculo côncavo à esquerda: plagiocefalia. Instrução rudimentar: ele mal sabe ler e escrever. Quando jovem, aprendeu o ofício de sapateiro no qual era bastante hábil. Uma pequena oficina que ele montara para o conserto de botas proporcionava-lhe um ganho suficiente para levar uma existência cômoda e para permitir-lhe essa elegância de toalete exagerada tão de acordo com o gosto de nossos mulatos e que os caracteriza de forma tão exata. Aos domingos, ele passeava na cidade, vestido com um redingote e usando uma cartola. Essa manifestação de suas futuras preocupações de grandeza é unanimemente confirmada por aqueles que o conheceram na época, que aliás elogiavam sua aplicação no trabalho. De 1865 a 1870, durante a Guerra do Paraguai, vamos encontrá-lo na Guarda Nacional. Ativo e bom comerciante, ele é encarregado da transmissão de correspondências entre as casernas. Ainda não contávamos com o telefone, e sua atividade como militar foi marcante e muito notada. Com o término da guerra, ele retoma suas atividades, e delas se desincumbe nas condições previamente indicadas. As informações sobre o período que se segue a esses acontecimentos são indecisas; nosso homem tem mais ou menos trinta anos; a fase atual começa.

Cândido abandonou sua profissão de sapateiro. Por quê? Não sabemos. Ele começa a vender bilhetes de loteria que oferece aos passantes, percorrendo as ruas. Alguns afirmam que ele empregava, nesse tráfico, procedimentos indelicados. Vendia bilhetes não premiados já sorteados anteriormente. Em seguida, os negociantes encarregam-no de pequenas cobranças. Foi então que alguns empregados do comércio, querendo rir à sua custa, o ridicularizam, excitando suas tendências a dar ordens, aguçando suas veleidades de grandeza. Cândido toma ares de importância e todos se esforçam para estimular seu amor-próprio, fazendo penetrar em seu espírito a idéia de que sua posição era humilde demais e excessivamente distante da que mereceria dada sua personalidade superior. Em meio a esses acontecimentos, um operário seu conhecido, subtenente da Guarda Nacional, veio a falecer; então, todos insistem tanto que a escolha para preencher a vaga deveria recair sobre ele, que Cândido acaba postulando sua candidatura. Aqueles que tinham planejado tudo isso por passatempo fizeram imediatamente inserir nos anúncios de um jornal da cidade a notícia anunciando sua promoção ao grau de subtenente da Guarda Nacional. Convencido da veracidade da notícia, muito satisfeito, Cândido aceita de bom grado um uniforme que lhe foi oferecido e deixou-se fotografar em roupas de oficial. Seu fraco era conhecido e sucessivamente ele foi elevado da mesma forma às patentes mais altas da hierarquia, até inclusive à de general. Fizeram-no então duque de São Salvador, generalíssimo, e casaram-no com ricas princesas. 
É preciso ver hoje como ele se comporta: com ares de superioridade, andar orgulhoso, o desejo de fazer bela figura sob a miserável toalete, o aspecto radiante da fisionomia, seu tom, as maneiras com que desempenha seu papel, o modo de atravessar as ruas e falar com as pessoas.

Suas convicções no que se refere à sua alta situação têm, no entanto, limites. Se, por exemplo, alguém fizer chegar às suas mãos um falso convite do governador do Estado ou de qualquer outro alto funcionário, ele evitará ir ao encontro desses personagens. Há mesmo quem acredite que sua conduta é ditada pelas vantagens que lhe proporciona, pois ele é bem recebido por certas pessoas da boa sociedade. Citam-se certos procedimentos seus marcados pelo selo da mais pura correção. Tudo isto ocorreu no tempo em que os eleitores no Brasil eram submetidos ao censo. Uma eleição vivamente disputada ia ter lugar. Um dos candidatos, por meio de documentos fabricados a partir do imposto legal pago por Cândido, teve acesso aos seus dados e obteve em seu nome um título de eleitor, que foi entregue ao titular. Mas nosso candidato não teve a precaução de garantir por promessa o voto de Cândido, que fora, ao contrário, prometido ao adversário.

Foi em vão que se tentou, por todos os meios possíveis, mesmo lhe prometendo vantagens muito exageradas, fazê-lo mudar sua decisão, e dar seu voto ao candidato que havia obtido seu título de eleitor: ele restou inflexível.

Alguns instantes de conversa com Cândido bastam para perceber que não é um espertalhão que se tem diante de si. Um impostor não conserva invariável, durante vinte anos, uma conduta em todos os pontos concordante com a alta opinião que ele possui de si mesmo.

Desejando ter dele uma nova fotografia, insisti para que ele posasse, levantando vários argumentos, entre os quais o de que seu retrato me tinha sido solicitado por várias revistas importantes do exterior. Sua resposta foi altamente paranóica: seria conveniente, ele diz, ter certeza de que não se tratava de nenhuma intriga amorosa destinada a afastá-lo de sua noiva, pois ele se via perseguido por senhoras de alta qualidade que não paravam de assediá-lo.

Não se descobre nele qualquer tendência para escrever sua biografia, talvez porque ele só saiba escrever muito imperfeitamente, ou talvez por outro motivo qualquer, pois ele rejeitou as propostas que lhe fiz a esse respeito. De qualquer forma, não deixa de ser verdade que ele sempre traz consigo uma caderneta onde são colados artigos de jornal que ele fez publicar, e que ele recortou cuidadosamente. Para ele, esses artigos de jornal são títulos que estabelecem sua posição social, da qual tem uma tão alta idéia.

Nada pode provar mais claramente sua ausência de julgamento do que esses recortes de jornal que ele mostra a cada novo conhecido, e que contêm as coisas mais estranhas, as asserções mais idiotas, mais ridículas, mais absurdas. 
Cândido tem um irmão que sempre desfrutou de boa saúde, mas do qual ele evita falar; chega mesmo a negar sua existência.

Lendo essa observação, parece inicialmente que nos encontramos na presença de um verdadeiro delírio de grandeza. Mas analisando-se cuidadosamente o doente, logo se reconhece que, nele, o temperamento paranóico com tendência à grandeza permitiu apenas uma convicção paranóica que sempre pode ser diferenciada de um verdadeiro delírio. Considerando a falta de senso crítico e a credulidade, tão fácil quanto inquebrantável, dos paranóicos, compreendemos muito bem que os meios empregados por aqueles que se deram à estúpida e maldosa tarefa de ridicularizá-lo, não poderiam deixar de inculcar-lhe uma convicção firme e constante. Escreviam para ele, em nome de personagens influentes ou altamente posicionados, cartas que lhe eram diretamente entregues por indivíduos enviados expressamente para esse fim ou, ainda, pelo correio. Ele recebia falsos telegramas assinados pelas mais altas personalidades do país. Fazia-se publicar nos jornais o texto de convites que lhe eram supostamente dirigidos, assim como notícias referentes a altos empregos a ele conferidos ou promoções das quais ele era objeto. Se acrescentarmos a isso a conspiração voluntária ou involuntária da maioria de seus conhecidos, que por diversão não perdiam a oportunidade de felicitá-lo por seus méritos e pelos testemunhos de consideração que lhe eram prestados, vamos reconhecer que o conjunto de todos esses fatos deveria inevitavelmente conduzir à implantação de uma convicção firme e profunda sobre seu valor no espírito desse homem ignorante, que mal sabe ler e escrever; nesse espírito desequilibrado, desprovido de qualquer senso crítico.

As convicções errôneas de Cândido não são espontâneas; elas lhe são impostas por uma verdadeira sugestão complexa e isso permite distingui-las, nesse matóide, de um verdadeiro delírio. Eis um exemplo da conduta censurável, em todos os sentidos, dos amigos desse doente.

Proceder-se-ia à designação do candidato para uma próxima eleição presidencial à República. Encontrei, na rua, o duque de São Salvador (Cândido) que me perguntou se eu havia lido o seu artigo. Respondi negativamente e desculpei-me com um pretexto qualquer. Ele imediatamente tirou do bolso um exemplar do Jornal de Notícias de 8 de novembro de 1901, e pediu-me para ler o seguinte:

\section{Agradecimento}

O Grande Sultão Almirante inglês, Generalíssimo, Chefe do mar e da terra, Conselheiro, Doutor Cândido Vieira dos Santos, duque de São Salvador. Eu não posso aceitar o cargo de Presidente da República para o qual fui designado pelo sr. dr. Campos Salles que, por telegrama que acabo de receber, me consulta a esse propósito; e isso por motivos imperiosos. Entretanto, agradeço sua 
Excelência, por tal testemunho de consideração; expresso o pesar que sinto de não poder satisfazer a sua demanda e peço-lhe perdão.

Haveria nessa idéia uma causa delirante qualquer? Tentei certificar-me. Mas me convenci facilmente do contrário. Cândido também me mostrou dois falsos despachos telegráficos, em papel oficial, assinados pelo presidente da República, que lhe tinham sido entregues e que eram concebidos mais ou menos nos seguintes termos: "Sua Excelência, Duque de São Salvador, Bahia. Vosso nome foi indicado para Presidente da República, próxima eleição. O sr. aceita? Esperamos tudo de seu patriotismo. Campos Salles.”

Esse fato bastou para provar que não há, em Cândido, espontaneidade delirante, mas sim falsas convicções nascidas de fortes sugestões complexas. Uma outra consideração concorre para a mesma demonstração; o desacordo que existe entre sua situação social precária e suas grandezas reclama uma explicação que o preocupa incessantemente. Ele aceita com a maior facilidade tudo o que lhe é sugerido a esse respeito. Um de seus supostos amigos, espírita declarado, e que busca convencer Cândido de suas grandezas por meio de práticas espíritas, faz com que ele acredite que sua situação atual é totalmente transitória; que o espírito de um grande homem francês está encarnado nele e que quando esse estado cessar, sua cor negra desaparecerá. Sua grande fortuna lhe vem de sua primeira noiva, uma princesa muito rica que, ao morrer, legou-lhe tudo o que possuía; se ele ainda não tomou posse dessa fortuna, é porque ele ainda não se casou com sua segunda noiva, que o espera.

Uma observação a ser feita é a de que Cândido não tem alucinações.

A seguinte observação apresenta provavelmente um caso análogo. Entretanto, não ouso afirmá-lo, pois o exame psicológico do doente não foi feito de modo suficientemente aprofundado para excluir positivamente a existência de idéias delirantes.

\section{Observação XV (pessoal)}

Idéias de grandeza num negro crioulo supostamente rei africano, tipo popular, muito conhecido no Rio de Janeiro, sob o nome de príncipe Obá.

Cândido da Fonseca Galvão era um negro baiano muito alto, corpulento. Ele tinha feito a campanha do Paraguai, onde se distinguiu por sua bravura. Uma ação espetacular na batalha de Curupaiti valeu-lhe a patente de subtenente. No fim da guerra foi morar no Rio de Janeiro onde, durante algum tempo, passou desapercebido; depois, um belo dia, revelou-se em público e logo se tornou um tipo popular de rua. Dizia descender de uma família real africana. Tinha as provas disso e, conseqüentemente, assumiu o título de príncipe Obá II d’África. Isso era apenas uma invenção de sua parte, provando que ele não tinha qualquer 
conhecimento da língua nagô, onde a palavra Obá significa rei e não outra coisa. Ele se arranjou para compor uma Corte, com sujeitos recrutados entre os negros africanos e a negras ambulantes da Praça da Sé. Tais sujeitos, que se mostravam orgulhosos de seu príncipe improvisado, cotizaram-se para lhe fazer uma lista civil.* Eles se ajoelhavam à sua passagem e lhe pediam a bênção.

Sabemos pouco sobre suas idéias de grandeza. Ele se dizia rei e se comportava como tal: suas idéias se revelavam principalmente em seu modo de andar e suas maneiras. Em seu livro Festas e tradições populares no Brasil, o professor dr. Melo Moraes escreveu a história do príncipe Obá. Ele lhe traça o seguinte retrato:

Tipo de rua mais curioso de ser visto que descrito. Assumia ares teatrais e só oferecia um interesse puramente exterior. Seu diálogo era superficial e sem espírito; a opinião que se tinha dele resultava principalmente de seu modo de se vestir e das maneiras que lhe eram particulares. Nos dias ordinários, para seus passeios habituais, ele usava um longo redingote preto e uma calça da mesma cor, imensamente larga, cuja boca, estreita, recaía sobre botinas em forma de funil. Na cabeça trazia uma cartola, colocada ao alto numa posição inclinada. Luvas de algodão branco, um guarda-chuva e uma bengala sob o braço completavam sua toalete. Além disso, usava um pince-nez com vidros fumês. Dava grandes passos, numa postura altiva, com o tronco ereto e movendo cadenciadamente os braços.

Respondia às vaias dos trocistas e dos delinqüentes com uma saudação graciosa, levantando o chapéu e depois fazendo com a mão um sinal de adeus a um passante qualquer que tivesse testemunhado o que acontecera. (Melo Moraes, s/d, p. 534)

Conheci o príncipe Obá no tempo em que eu era estudante na Faculdade do Rio de Janeiro e essa descrição do dr. Melo Moraes é bastante exata.

Em consideração aos serviços militares do subtenente Galvão, o velho Imperador Dom Pedro II consentia em recebê-lo em suas audiências. Galvão aproveitava para mostrar seu uniforme.

Após a proclamação da República (1889), o príncipe Obá, nos diz o dr. Melo Moraes, apresentou-se ao palácio para saudar o imperador. Tendo sido expulso, ele começou a gritar: "Viva a Monarquia!”. O governador provisório o destituiu; pouco depois, ele morreu.

A condescendência do velho Imperador, assim como os inúteis rigores do governo republicano com relação a esse infeliz, mostram com igual eloqüência que o

* Lista civil: verba alocada ao chefe de Estado ou ao Rei pela nação, para sua manutenção (nota da revisora técnica). 
delírio paranóico pode muito bem passar desapercebido aos olhos das mais altas autoridades, que nem sempre sabem abrir com sabedoria as portas do hospício.

Há uma categoria especial de desequilibrados que não hesito em classificar entre os paranóicos sem delírio, apesar da opinião contrária de um brilhante alienista, Silvio Venturi (1899): quero dizer os mentirosos-natos. Em sua importante e curiosa monografia sobre os mentirosos, esse autor, preocupado com sua teoria dos característicos, esforçou-se por cavar um abismo entre os mentirosos-natos e os loucos; sobretudo, as importantes relações entre a mentira e a paranóia são quase intencionalmente relegadas a um plano secundário. Aliás, ele afirma sem hesitação que o mentiroso-nato é um desses desequilibrados que estão sempre a um passo do hospício sem nunca aí ingressar, o que, na nossa opinião, é menos um efeito de sua qualidade de característico social, como quer Venturi, do que de sua qualidade de alienado lúcido, desprovido conseqüentemente de um verdadeiro delírio; vemos isso acontecer com degenerados inferiores, nada mais que característicos.

Maynert, ao contrário, desenvolveu uma idéia exata sobre as relações da mentira e do delírio paranóico:

O delírio de grandeza - ele escreve - no que se refere à invenção das idéias delirantes, encontra-se estreitamente ligado à mentira. Já vimos que os mentirosos sãos inventam, de fato, sem razão, pois eles não têm outro objetivo senão colocar em evidência o engrandecimento de seu $e u$ que pode ainda ser verdadeiro, mas sobre o qual eles se comprazem em contar histórias. A amplificação das perseguições é, em si própria, uma expressão do engrandecimento das relações do eu. (Maynert, s/d, p.139)

Selecionei várias observações relativas a mentirosos-natos e que correspondem exatamente à bela e rigorosa descrição de Venturi. A degenerescência revela-se em toda parte com tal abundância de provas que a contestação é impossível. Mas é indiscutível que na base desse estado mental encontra-se, mais ou menos claramente, uma idéia exagerada do $e u$, uma forma, uma modalidade equivalente ao sentimento de grandeza. Em nossas observações, há sobretudo uma onde o lado paranóico desse sentimento de grandeza se impõe com a maior eloqüência. Infelizmente, o sujeito é excessivamente conhecido do público brasileiro e durante sua passagem pela alta administração do país cometeu atos que o fariam imediatamente ser reconhecido se os citássemos abertamente. Não podemos assim apresentar essa observação com uma análise suficientemente detalhada para dar-lhe um caráter comprobatório. Desde cedo, o delírio paranóico manifestado pelo orgulho e a opinião exagerada que esse indivíduo tem de sua ciência e de sua alta sabedoria nele imprimiu sua marca particular. Sua tese de doutorado é o mais claro e nítido atestado de seu desequilíbrio, que um concur- 
so para uma cátedra de nível superior só veio confirmar. Dotado de uma espantosa capacidade de elocução, que quase chega à logorréia, o mais simples, o mais banal dos fatos serve-lhe de tema e basta-lhe para encontrar assunto para a enumeração das mais extraordinárias coisas, onde seu autofilismo mostra-se sem medida: ele se apresenta como tendo percorrido o mundo inteiro, freqüentado os mais altos personagens e obtido os diplomas das mais renomadas faculdades. Seria necessário um volume inteiro para contar todas as suas façanhas, todos os seus relatos, cujos fatos vêm a todo instante chocar-se contra a possibilidade da verdade. A todo instante e a respeito de tudo, ele provoca discussões, e para fazer prevalecer sua opinião, não sente qualquer embaraço; inventa citações e apela para autoridades que nunca existiram. Sua conduta jamais foi marcada por qualquer sinal de escrupulosa correção. Apesar de tudo, seu estado mórbido é tão pouco aparente que ele evitou o hospício e pratica sua profissão; chega mesmo a ser admirado por pessoas ingênuas ou pobres de espírito e conseguiu tornarse admissível em um concurso.

É em vão que Venturi prolonga seus comentários; uma de suas observações demonstra que a fase de grandeza do paranóico pode ser constituída pelas criações mentirosas de um verdadeiro mentiroso-nato, o que estabelece claramente e melhor que tudo a natureza paranóica desses casos não totalmente desenvolvidos, em que o estado mental paranóico reduziu-se ao do mentiroso-nato.

F) Os perseguidos-perseguidores (Falret e Magnan). Os querelantes (Querulanten Wahnsinn dos alemães, querulanti litiganti dos italianos).

Eles constituem uma espécie muito conhecida dos paranóicos indiferentes bem estudados seja na França, seja na Alemanha ou Itália. Essa forma clínica da paranóia existe com toda certeza entre os negros e mestiços.

A seguinte observação é um desses casos, bastante completo e interessante.

\section{Observação XVI (pessoal)*}

Um mestiço perseguido-perseguidor. Preocupações causadas pela existência de tesouros escondidos; solicitações de concessões feitas ao governo; escavações. Luta contra seus sócios e o governo. Idéias de perseguição; ameaças de morte a seus supostos inimigos.

M.N., mestiço escuro, com cinqüenta e seis anos. Boa saúde. Sem estigmas notáveis, físicos ou psíquicos, de degenerescência. Antecedentes pessoais

* Esta observação foi publicada na tese do dr. Mendonça, Qual a melhor interpretação a ser dada ao termo paranóia? Bahia, 1893. A redação que lhe foi dada carece de precisão científica (nota de Nina-Rodrigues). 


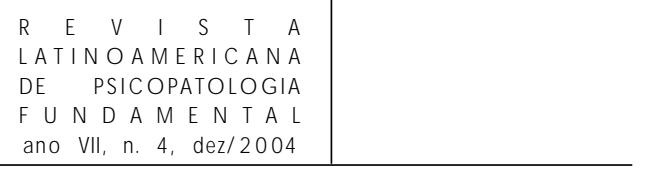

e hereditários desconhecidos. Instrução muito rudimentar: ele não sabe escrever. Tendo feito serviço militar na qualidade de marinheiro, fez várias viagens à Europa e à África.

Uma idéia fixa dominava esse doente: ele acreditava que sabia da existência, em um vilarejo bastante afastado, situado no interior do Estado, de tesouros fabulosos encerrados em um cofre-forte enterrado; esse cofre-forte continha os doze apóstolos em ouro de tamanho natural, pedras preciosas e moedas de ouro e prata. Ele tinha informações, além disso, sobre numerosas riquezas enterradas pelos jesuítas que tinham antigamente habitado um convento erigido nesse vilarejo, e que temiam as conseqüências da invasão holandesa de 1711. Então, tratavase, para ele, de encontrar todos esses tesouros e com esse objetivo, solicitou inicialmente ao governo imperial, e depois ao da República - a autorização necessária para praticar escavações no convento (que, aliás, tinha pertencido não aos jesuítas, como ele pensava, mas sim aos franciscanos) e em qualquer outro lugar que se mostrasse necessário. A existência dessa fortuna colossal lhe teria sido revelada por uma dama portuguesa de linhagem real, que o tinha criado e lhe teria entregue os papéis correspondentes. A mãe de M.N. veio mais tarde habitar um vilarejo vizinho à cidade da Bahia (Salvador). Ele lhe havia confiado os papéis, que ela guardou numa caixa de latão e enterrou no quintal de sua casa. Mas M.N., indo procurá-los a pedido de pessoas da Bahia, não mais os encontrou. De qualquer forma, M.N., que se encontrava inicialmente no Pará, garantia que o governo imperial lhe tinha, por intermédio do presidente daquela província, prometido a autorização solicitada. Entretempo, a queda do Imperador é proclamada. M.N. acorre ao Rio de Janeiro e solicita do governo republicano a recondução do consentimento dado pelo governo procedente. Mas a autoridade competente permanece surda a essa demanda e M.N. interpreta essa recusa de modo francamente paranóico: o ministro era um ambicioso que desejava participar do empreendimento na qualidade de sócio, e que não podendo desobedecer ao presidente que já havia dado a autorização, tentava criar-lhe os mais sérios obstáculos; foi com esse objetivo que ele deu aos governadores dos Estados a faculdade de atribuir tais concessões. Essa decisão é verdadeira: ela era uma conseqüência da nova forma de governo adotada pelo país. M.N., em suas interpretações delirantes, incorpora-a às suas idéias de grandeza.

Sua coragem e persistência não enfraquecem. Ele vem para a Bahia e obtém do governador do Estado então no poder, homem notável e professor eminente de nossa Faculdade de Medicina, a autorização tão desejada, tão buscada. Aí está uma prova não equívoca de sua lucidez aparente. Nosso homem afirma que, após ter obtido a concessão, muitos banqueiros ofereceram-se para ajudá-lo. Muitos sindicatos estrangeiros também se apresentaram com o mesmo objetivo, mas ele recusou todas as propostas, porque queria que a glória da descoberta fosse toda 
sua. Nesse meio tempo, ele aceita o auxílio de um amigo e as escavações começam. Mas esse logo abandona M.N., cuja instabilidade mental ele reconheceu. Apesar disso, os trabalhos continuaram e os edifícios contíguos ao convento já estavam ameaçados quando a municipalidade interveio e ordenou a suspensão dos trabalhos. Uma luta se trava então entre M.N. e diferentes personagens que ele faz atacar na imprensa cotidiana; a intervenção do governador é reclamada mas, como resposta, este caça a autorização. M.N. dirige-se aos tribunais, mostrando a maior atividade na defesa de seus interesses. Vai ao Rio de Janeiro e entra com uma petição ao Tribunal Federal. Ele se queixa de ser perseguido, ameaçado e destituído de seus tesouros. Torna-se perseguidor por sua vez e promete matá-los. Mas a morte vem surpreendê-lo e aniquila todos os seus projetos.

As concepções mórbidas desse doente nascem das lendas populares, segundo as quais colossais riquezas teriam sido guardadas nos conventos brasileiros pelos jesuítas quando o marquês de Pombal ordenou sua expulsão. É essa sua fonte de inspiração. Conheci pessoalmente M.N. e examinei-o várias vezes; nunca detectei a presença de alucinações. Os fatos que o doutor Mendonça apresenta como sendo alucinações visuais de M.N. são tirados de uma lenda muito conhecida em Pernambuco e em outros Estados do Norte do Brasil; o alienado apenas apropriou-se dela e colocou-se como seu protagonista. Mas verdadeiramente, a edição das concepções querelantes nos negros é mais humilde do que esta, pois eles se encontram ainda bem atrasados na evolução jurídica. Observei dois ou três casos de paranóicos querelantes negros, totalmente rudimentares.

\section{IV - Semiologia da paranóia nos negros}

O estudo precedente demonstra claramente que a manifestação da paranóia nos negros é fundamentalmente a mesma que a paranóia nos brancos. Assim, não há qualquer interesse em se repetir coisas suficientemente conhecidas e podemos então nos limitar ao exame de algumas questões capitais.

Alucinações: A paranóia nos negros, assim como nos brancos, pode se manifestar com ou sem alucinações, e estas podem afetar a sensibilidade geral ou ser não somente motoras, mas também sensoriais ou psíquicas. A freqüência das alucinações visuais auditivas é mesmo notável. Se, em alguns casos, as alucinações visuais pertencem à paranóia, outras vezes elas indicam a coexistência do delírio alcoólico.

Mas o que nos parece ter um significado particular nos negros são as alucinações motoras e psicomotoras. Tanzi sublinhou a importância que pode ter 
para o estudo das alucinações na raça negra o estudo de um fenômeno bem conhecido: o hábito que têm os negros de pensar em voz alta.

Talvez seja ainda - ele escreve - uma mistura de hiperacusia e de alucinação que conduz o negro, como o paranóico, a falar muitas vezes para ele mesmo, deixando-se levar a longos diálogos solitários, o que faria com que um alienista percorrendo o centro da África esquecesse, por um momento, a nostalgia dos asilos. (Tanzi, 1896)

O vocábulo diálogo não é rigorosamente verdadeiro. O que freqüentemente se observa nos negros, tanto na África quanto em nosso país, é seu costume de falarem sozinhos. Encontrei muitas vezes, em meu caminho, nos domingos em que ia fazer minhas visitas semanais ao Asilo São João de Deus, uma negra que falava sozinha e em voz alta, de tal modo que cheguei a pensar, antes de me aproximar, que ela estivesse conversando com alguma companhia.

Não poderíamos concluir, a partir de tal fato, pela existência de alguma alucinação; ele nada mais indica do que a predominância do tipo motor-verbal no negro. A distinção desses dois fatos é fácil, pois encontramos no negro, além do motor-verbal normal, o alucinado motor mórbido. Mas como fazer essa distinção? As linhas seguintes, de Séglas nos informam:

Lembrem-se das pessoas que falam sozinhas. Quem de vocês não cruzou na rua com motores-verbais desse tipo? Entretanto, todos esses indivíduos se distinguem por um sinal capital: é que eles têm consciência que as palavras que eles pronunciam são, sem dúvida, a expressão de seu pensamento. Ora, nos alucinados motores, encontramos exatamente os mesmos fenômenos com os mesmos graus, mas com a diferença fundamental de que as palavras que eles pronunciam não estão em relação com suas idéias conscientes. É aí que se constitui a verdadeira alucinação verbal-motora. (Séglas, 1897, p. 16)

Se a freqüência do tipo verbal-motor nos negros explica a das alucinações verbais-motoras da paranóia, ela também nos fornece a chave da freqüência dos desdobramentos da personalidade observados na raça negra, não somente na paranóia (observações VI e XIII), mas principalmente nos estados de possessão histérica que os negros chamam de estado de santo quando eles celebram suas cerimônias fetichistas ou praticam seus atos de feitiçaria.

As mesmas observações devem ser notadas no que diz respeito à importância, para as alucinações motoras, dos movimentos corporais tais como acontecem nas contorções e gestos durante as danças sagradas ou profanas que os negros tanto apreciam.

Conteúdo do delírio: O conteúdo do delírio paranóico nos negros é curioso quando o consideramos sob os dois seguintes pontos de vista: $1^{\circ}$ ) o da capacidade da organização do delírio; 2º o da origem atávica de seu conteúdo. 
Teixeira Brandão e Franco da Rocha, entre os alienistas brasileiros, acreditam que a pobreza e a estreiteza do delírio paranóico nos negros dependem de sua inferioridade mental. Esse é um ponto muito discutível e que nossas observações parecem contradizer. Acredito que nem sempre tenhamos uma idéia clara da capacidade mental dos negros. É certo que podem existir populações ou tribos de negros com tal inferioridade mental que quase se confunde com o idiotismo ou com a imbecilidade; mas há numerosos casos em que a inferioridade mental do negro não se refere senão às qualidades superiores da inteligência. Esse ponto foi muito bem esclarecido por Corre, cuja opinião, idéias e vislumbres a esse respeito são plenamente confirmadas pelo que conhecemos do negro até hoje. Escreve Corre:

Exagerou-se muito a inteligência do negro. Qualquer que tenha sido o meio em que foi criado, ele nunca produziu nenhum conceito de grande extensão, nem atingiu os altos cumes da arte ou ciência. Alguns sujeitos puderam mostrar qualidades brilhantes ou adquirir uma vasta instrução (...). Na superfície, fornecer boas reservas ao mundo do funcionamento colonial; observem as individualidades que se destacam assim, exceções rarefeitas, e constatarão quão pouco elas ultrapassam o nível médio das categorias profissionais às quais pertencem, isso se conseguirem ultrapassá-lo. Arranhem mesmo, com método e precaução (...) o verniz vai ficar em seus dedos, e vocês descobrirão por baixo a enganosa reunião de faculdades secundárias, que deram a ilusão de talento. Com memória e uma espantosa potência de imitatividade, o negro consegue assumir aparências peculiares. $\mathrm{O}$ régulo africano tem um ar de grande majestade. $\mathrm{O}$ aluno, ao sair dos bancos de um colégio, tem excelentes modos e é capaz de abordar com sucesso exames onde a seleção se faz menos segundo o mérito sério, e mais pela posse de fórmulas rotineiras. O jovem, ao deixar as grandes escolas, terá adquirido a boa postura de um advogado, de um magistrado ou médico. No fundo, nenhum deles despojou-se de seu valor étnico. Em todos, a capacidade de raciocínio é restrita ou ausente; uma enorme dose de confiança em si próprio, muitas aquisições de efeito ou a cabotinagem natural parecem impô-la, mas unicamente àqueles cuja perspicácia deixa a desejar ou voluntariamente se esquiva. Acrescentarei que esses emergentes, caso se mantenham à tona, sustentados pelo ambiente, desde que este apoio falte, decaem muito baixo. (Corre, 1894, p. 72)

Portanto, com o auxílio das faculdades, aliás inferiores, da memória e da imitatividade que o negro possui em alto grau, é evidente que ele pode atingir uma cultura intelectual elevada, mais que suficiente para fornecer os elementos de um delírio complexo e bem sistematizado. Devemos, conseqüentemente, admitir que tanto no negro quanto no branco, bem guardadas as proporções relativas de capacidade mental de cada raça, existem homens inteligentes e ininteligentes, os primeiros dotados de uma grande capacidade mental, os segundos reduzidos a uma capacidade bastante inferior. 


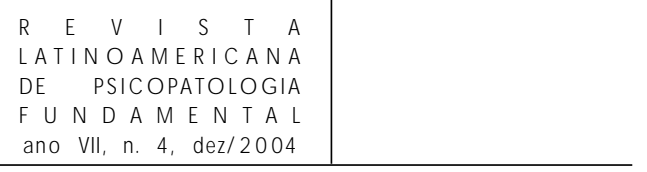

É a esta última circunstância que pediremos a explicação para a falta de conexidade de muitos dos delírios dos negros. Dizem Tanzi e Riva (1886, p. 76): "Há, seja nos paranóicos, seja nos homens sãos, uma aristocracia intelectual, mas também uma plebe. É assim que muitas vezes nos encontramos na presença de delírios risíveis, pobres, com elementos desconexos, e por isso privados de qualquer apoio lógico”.

Por vezes, acontece dos paranóicos negros não fornecerem precisões quanto a seus perseguidores; freqüentemente, eles nem chegam a atribuir a perseguição a um ser determinado, e se limitam a dizer: "Me falam etc." Franco da Rocha refere-se a esse fato atribuindo-o à inferioridade mental da raça negra. Pensamos que aqui ele pode estar cometendo um pequeno erro de interpretação. Pois é antes no desenrolar do delírio que devemos encontrar a explicação desse fato. Ao estabelecer que, na designação do perseguidor, os paranóicos vão gradualmente das fórmulas vagas e sem precisão às fórmulas cada vez mais precisas e definidas, Séglas (1897, p. 505) nos diz: “As fórmulas indefinidas denotam um delírio pouco preciso, ainda mal sistematizado e podem assim nos informar sobre a evolução da doença, o alguém marcando o começo, a coletividade um período já mais avançado; a designação precisa revela um delírio ainda mais nítido”. Portanto, nos casos de que se ocupa Franco da Rocha e que citamos previamente, poderia tratar-se de delírios de início súbito, ainda pouco avançados, em que somente mais tarde a designação do perseguidor será precisada.

Ainda que subsista uma grande diferença entre a capacidade mental dos negros e dos brancos, é completamente verdade que os negros são capazes de uma perfeita sistematização delirante paranóica, como provam as observações I e $\mathrm{V}$, pois o delírio se constitui à custa das aquisições cognitivas de nosso eu secundário e sua grande memória e imitatividade lhes permitem essa aquisição, aliás sem grande solidez.

Entretanto, a existência de um delírio bem sistematizado nos sujeitos de raça negra só prova rigorosamente uma coisa, ou seja, que nessa raça podemos encontrar indivíduos cuja inteligência é bem desenvolvida. Mas fora desses casos que não constituem a regra, a inferioridade mental dessa raça se manifesta perfeitamente no desvio paranóico e não exatamente, eu diria, no delírio paranóico. As formas bem desenvolvidas dos delírios paranóicos crônicos são raras ou ainda não observadas nos negros; é essa a opinião unânime dos alienistas brasileiros. Acrescento, para maior precisão, que minhas observações permitem afirmar que o delírio bem sistematizado denuncia ou um negro proveniente dos povos mais avançados da África ou um negro mestiço, pois o cruzamento com a raça branca dá aos negros uma indiscutível superioridade intelectual.

No negro médio, o verdadeiro representante da raça, predominam os delírios paranóicos incoerentes, rudimentares; a paranóia não plenamente desenvolvida, 
as paranóias agudas, sub-agudas ou crônicas, onde predomina a associação do elemento confusional, tornam-se freqüentes. A denominação de confusão mental paranóica de Del Grecco lhes é bem mais aplicável.

Entretanto, como demonstramos, a paranóia é muito freqüente nos negros, ao menos nos negros americanos, aos quais é imposta uma civilização muito mais complexa do que a que possuíam os negros trazidos da África. As coisas não poderiam se passar de outra forma. A pouca solidez da síntese psíquica, que em última análise constitui a personalidade, o vigor, a predominância dos mais elevados instintos sociais, deve facilitar nas raças inferiores a eclosão da paranóia, assim como outros estados mais ou menos profundos da desagregação da personalidade.

Deste ponto de vista, acreditamos mesmo que não se deva confundir o maior ou menor vigor de sistematização paranóica com a exuberância, a riqueza e o brilho das manifestações delirantes. Estas últimas dependem imediatamente da cultura intelectual e da solidez da inteligência, que resistirá tão mais à confusão quanto mais sólida for. A sistematização paranóica depende, entretanto, de uma lei mais geral - a grande lei da associação sistemática - que tem sua base, como demonstrou Paulhan, na organização psíquica e que rege todas as manifestações psíquicas, tanto a inteligência quanto os sentimentos e a vontade. Uma forte manifestação paranóica pode se revelar ao mesmo tempo que um delírio pobre ou quase nulo, como demonstram as observações XIV e XV, pela atitude, pelos atos, pela conduta dos alienados. Não se pode, portanto, reduzir toda a sistematização paranóica à simples sistematização delirante.

Ora, nada nos autoriza a acreditar que os instintos, os sentimentos fundamentais, sejam mais fracos nas raças inferiores do que nas raças superiores; se eles são menos disciplinados, eles são, em compensação, mais violentos. E como a paranóia consiste essencialmente na excitação do instinto de conservação, compreende-se que esse instinto vigoroso, pouco dominado por sentimentos sociais superiores nas raças inferiores, ao repercutir numa inteligência ainda mal organizada e mal desenvolvida, deva produzir a desordem, a confusão, o estupor, que se associam tão freqüentemente nos negros com a paranóia, em vez de provocar os delírios rigorosos e sistematizados das formas complexas da paranóia. Ou, se essa repercussão for menos violenta, ela irá se revelar na sistematização paranóica dos atos, da conduta, da atitude do paranóico, com uma intervenção fraca ou nula do delírio.

Assim, a observação vem confirmar os princípios desta parte da teoria de Del Grecco que aceitamos: "Se essa doutrina é verdadeira” - me escreveu o eminente professor - "os delírios paranóicos nos negros deverão ser mais do que nunca atrofiados, ao mesmo tempo que a conduta anormal de seu caráter irá se tornar totalmente evidente.” 
A observação sanciona esta previsão, mesmo na contraprova dos delírios bem sistematizados estudados em negros de maior aptidão intelectual ou em mestiços.

No que se refere à origem atávica do conteúdo do delírio, nossas observações, à primeira vista, confirmam plenamente a teoria de Tanzi e Riva; apenas em alguns casos o delírio não repousa em preocupações e idéias de feitiçaria. Em uma observação (observação I), a idéia do talião é evidente, pois a doente tenta se vingar da alucinação de queimadura jogando água fervendo em sua suposta perseguidora. Na observação X, encontramos uma concepção animista bastante curiosa e totalmente primitiva. Essa aparência é completamente ilusória. Sob o fraco verniz de civilização que cobre as raças inferiores da população brasileira, o fundo selvagem mantém-se inalterado em todo seu vigor; ele suplanta a todo instante a educação recebida em nosso meio, ou realiza com ela uma simples mistura, de onde por vezes resultam curiosas associações. Os numerosos fatos que reuni e publiquei anteriormente confirmam isso de modo superabundante. Mas para não deixar de publicar fatos novos e mais sugestivos, irei resumir um processo curioso. Esse processo é apenas uma cena de nossa vida corrente, semelhante a mil outras que ocorrem e se reproduzem em nossa sociedade, e que me proponho a estudar mais tarde sob o ponto de vista da criminalidade brasileira, pois ele é pleno de ensinamentos.

Esse caso, ainda pendente diante do Tribunal Superior do Estado, é conhecido sob o nome de caso do Rei Congo (Rei do Congo).

Um grupo de curandeiras guiadas por uma feiticeira mulata propôs-se, em 1898, a curar uma moça sofrendo de ataques histéricos, que eles atribuíam a uma possessão demoníaca. A líder dessa tentativa, ela mesma possuída de um espírito, de uma divindade particular, o Rei Congo, fez submeter a jovem doente aos mais bárbaros tratamentos, a fim, dizia ela, de expulsar de seu corpo o espírito do mal. Para começar, ela foi cruelmente açoitada com urtigas, e depois, diziam, fizeram-na engolir água quente e mesmo fervente; finalmente, surraram tanto e tão bem o diabo, que julgaram que o momento propício para expulsá-lo tinha chegado, e para isso fizeram com que a infeliz doente bebesse chumbo derretido. Como se pode imaginar, o diabo não foi expulso, mas a moça morreu. De qualquer forma, o que nos interessa, principalmente neste momento, é a convicção inabalável sob o domínio da qual agia esse bando de mais ou menos dez negras ou mestiças, em sintonia total para atingir o mesmo objetivo. Mais ainda, é a fé geral que a população concede às feitiçarias, levada a tal ponto que o juiz, o sr. Praguer, teve que tomar sérias medidas para evitar, na localidade em que estes fatos aconteceram, o desenvolvimento de uma verdadeira epidemia psíquica; e ainda mais curiosa é a convicção totalmente enraizada dos criminosos aprisionados na Casa de Correção e que fui chamado a examinar: não somente acreditam com 
uma fé ardente na utilidade e santidade de sua intervenção, mas conseguiram comunicar essa fé aos co-detentos e mesmo aos guardas.

Em conseqüência, as mais elementares crenças animistas das práticas de feitiçaria, longe de serem um fenômeno atávico de nossa população, são, ao contrário, um estado normal; elas representam a fase de civilização que pertence, de fato, a essa população, e que as superfícies de uma civilização mais avançada, que ela em aparência adotou, não conseguiram modificar.

Esse fato é tão natural e chegamos, através de nossos estudos sobre a psicologia dos negros, a vulgarizá-lo tanto, que conseguimos, através de exames psiquiátricos, demolir especulações interesseiras que repousavam em casos de alienação imputada a negros fetichistas, mas saudáveis.

Certa pessoa, desejosa de se fazer nomear curador dos bens de um negro, reclamava sua interdição sob o pretexto de que ele apresentava idéias delirantes de feitiçaria. Meu colega e amigo, o Professor Mateus dos Santos e eu, fomos encarregados judicialmente de examiná-lo e demonstramos que, embora ele acreditasse em feitiçarias, não era alienado, e assim a interdição não foi declarada.

Conseqüentemente, o delírio paranóico dos negros referindo-se à feitiçaria, sobre idéias animistas, de talião, não confirma a opinião que quer nele ver a reprodução de uma fase já percorrida do espírito humano; ele prova exatamente o contrário: que são preocupações do momento, idéias dominantes da época em que vive o alienado, que estão em sua origem. Ele se constitui com os conhecimentos adquiridos pela educação recebida no meio onde o indivíduo formou seu espírito.

A comparação do delírio animista e de feitiçaria dos negros com o mesmo delírio nos brancos nos fornece a contraprova desse fato.

Não é indiferente notar - escreve Séglas - que um doente acuse os feiticeiros, os duendes, os jesuítas, ou a polícia. Há, nesses casos, diferenças importantes podendo informar sobre a educação, o nível intelectual do doente, e em nossos meios civilizados, as idéias de perseguição por feitiçaria não se encontram senão nos indivíduos pouco cultivados ou fracos de espírito. (1897, p. 505)

Assim, nos negros, em vez de se manifestar em indivíduos onde poderia ser um fenômeno atávico, o delírio de feitiçaria se manifesta em indivíduos que acreditam na possibilidade da feitiçaria.

\section{Conclusões}

As observações precedentes nos levam às duas seguintes conclusões: primeiro, a paranóia não é uma conseqüência direta da herança atávica de 
qualidades psíquicas normais outrora presentes na espécie. O paranóico não é um anacronismo, um ancestral que renasce hoje de uma sucessão atávica. O atavismo paranóico é um fenômeno degenerativo e representa uma parada de desenvolvimento mental mais ou menos complexo, que se revela clinicamente desde a infância sob formas originárias, ou que tendo sido dominadas durante algum tempo por um equilíbrio ou uma compensação mental mais ou menos instável, pode se manifestar sob a ação de um choque, de um desarranjo ou de uma doença psíquica em uma idade mais avançada; toma então a forma de um delírio sistematizado ou Verrücktheit paranóico; segundo, o atavismo paranóico não é a causa da paranóia; é sua condição psicofisiológica. De acordo com os ensinamentos de Mathias Duval, o atavismo é o substratum anatomopatológico, a condição morfológica das manifestações psíquicas da paranóia, cujas verdadeiras causas são as da degenerescência, e devem ser buscadas nos fatores físicos, fisiológicos e sociais.

Se, nos antecipando a futuros estudos, aplicamos estes princípios à interpretação do crime, cujas analogias sociais com a paranóia estudaremos proximamente, logo constatamos a impropriedade das discussões e das lutas engajadas entre os partidários da origem biológica desse fenômeno e os da origem sociológica.

Os fatores físicos e sociais são certamente as verdadeiras causas do crime que, assim, é um fenômeno social; mas essas causas são remotas e não podem produzir o crime senão produzindo biologicamente a razão imediata do crime. Ou seja, conseqüentemente, seu fator social.

Portanto, é erroneamente que Venturi busca substituir a teoria biológica do criminoso de Lombroso por sua teoria sociológica dos característicos. Trata-se não de substituir, mas de interpretar, pois as teorias biológica e sociológica se completam, e não se excluem.

A teoria dos característicos de Venturi é altamente verdadeira, mas há erro na sua forma de desenvolvê-la, que além de tudo é incompleta. Sem dúvida, a sociedade compõe-se na sua maioria de indiferentes ou de característicos cujo número será tão maior quanto mais civilizada for a sociedade; mas estes são apenas um efeito da aplicação sociológica da lei spenceriana da segregação.

É a divisão do trabalho e das funções sociais que cria os característicos ou adaptados, mas ela os cria modelando-os organicamente. Venturi o confessa:

Por meio de quais antecedentes biológicos se produzem os característicos natos? Pela ação hereditária que transmite as características produzidas, repetidas e consolidadas das gerações precedentes. O processo de formação social se simplifica através da hereditariedade e uma atitude produzida pela ação da luta pela vida torna-se estável, orgânica e harmônica. (Venturi, 1899, p. 35) 
Portanto, é com razão que Lombroso afirma que um tipo psicofisiológico especial deve corresponder ao criminoso, pois ele é um característico.

Venturi erra, principalmente, ao sustentar que os característicos sempre têm um papel social útil. Ele esquece que a adaptação social só é possível por um duplo trabalho de integração e de desintegração e que, em ambos, os últimos resultados, ou seja, a adaptação perfeita e a eliminação total não são obtidas num único lance, mas gradualmente, lentamente, sendo que, tanto durante o trabalho de adaptação quanto o de eliminação, tipos intermediários são criados e podem ser mais ou menos característicos.

O homem virtuoso e o criminoso são igualmente característicos, pois ambos são produtos da adaptação social; mas o primeiro é um produto de assimilação, de aperfeiçoamento social, um tipo evolutivo, enquanto o outro é um produto desintegrativo da eliminação social, um tipo involutivo. Pouco importa que ao criminoso, assim como aos característicos involutivos em geral, correspondam ainda no meio social em que vivem certas funções determinadas; é essa a condição de sua existência. Não podem existir característicos sem a existência de condições sociais às quais eles devam se adaptar.

Mas assim como os criminosos, as condições ou funções sociais às quais eles se adaptam e que os criam estão condenadas a desaparecer ou a se transformar; elas também são produtos de eliminação, de depuração social.

Uma única reserva se impõe: não devem ser englobados entre os criminosos involutivos todos aqueles que as leis e os governos consideram como tais.

\section{Referências}

Corre. L'ethnographie criminelle. Paris, 1894, p. 72.

Del Grecco. Sulle varie forme de confusione mentale. Il manicomio moderno,18971878.

Krafft-Ebing, R. Traité clinique de psichiatrie (tradução francesa). Paris, 1897, p. 411. Maudsley. La pathologie de l'esprit (tradução francesa). Paris, 1883, p. 317.

MAYNERT. Lezione cliniche di psichiatria.

Melo Moraes Filho. Festas e tradições populares no Brasil. Rio de Janeiro, s/d, p. 534.

Nery, M. História e patogenia da Paranóia. Rio de Janeiro, 1894, p. 26.

Paulhan. L'activité mental et les éléments de l'esprit. Paris, 1899, p. 411.

SÉGLAs, J. Leçons cliniques sur les maladies mentales et nerveuses. Paris, 1897.

TANZI. (...) nella patologia mentale. 1896 (restante ilegível).

TANZi e Riva. La paranoia. Reggio-Emilia, 1886, p. 76.

Venturi, S. La mostruosità dello spirito. Milão, 1899. 